\title{
The Purification of Biogas with Monoethanolamine (MEA) Solution Based on Biogas Flow Rate
}

\author{
Yohandri Bow ${ }^{1, *}$ Leila Kalsum ${ }^{2}$ Abu Hasan ${ }^{2}$ A. Husaini ${ }^{3}$ Rusdianasari $^{2}$ \\ ${ }^{1}$ Energy Engineering Department, Politeknik Negeri Sriwijaya, Palembang, 30139 Indonesia \\ ${ }^{2}$ Renewable Energy Engineering Department, Politeknik Negeri Sriwijaya, Jalan \\ Srijaya Negara, Palembang, 30139 Indonesia. \\ ${ }^{3}$ Chemical Engineering Department, Politeknik Negeri Sriwijaya, Jalan Srijaya, \\ Negara, Palembang, 30139 Indonesia. \\ *Corresponding author. Email: yohandrimk.2020@gmail.com
}

\begin{abstract}
Biomass is a plant material which is quite abundant in Indonesia. Utilization is also currently undergoing development. One of the uses for biomass is conversion to biogas. Biogas is a renewable energy source that can be used as a substitute for fossil energy. Biogas can be produced by utilizing organic materials that are no longer used through anaerobic digestion processes. In the process of producing biogas as an environmentally friendly fuel, it is necessary to first wash the biogas. The $\mathrm{CO}_{2}$ and $\mathrm{H}_{2} \mathrm{~S}$ content in biogas reduces the efficiency of the combustion process and causes corrosion of machining components. Biogas purification by absorption is a way to reduce levels of $\mathrm{CO}_{2}$ and $\mathrm{H}_{2} \mathrm{~S}$ contained, so that the biogas produced can be used as fuel. In this study, absorption using a packed bed scrubber and monoethanolamine solution and varying the biogas flow rate. The results of biogas purification using $7 \mathrm{M}$ monoethanolamine solution decreased $\mathrm{CO}_{2}$ and $\mathrm{H}_{2} \mathrm{~S}$ levels and increased methane gas production up to $87.6 \%$ with a biogas flow rate of $5 \mathrm{~L} /$ minute.
\end{abstract}

Keyword: biogas, packed bed scrubber, purification, renewable energy

\section{INTRODUCTION}

Fossil fuels such as oil and coal is the main energy source in Indonesia, will be but these energy sources have devastating effects on the environment, including air pollution, greenhouse gas emissions and global warming. Another problem is the high price of fossil fuels, the increase in the number of imports of petroleum due to national fuel consumption. Petroleum energy ranks first in the composition of the national energy mix, which is around $48 \%$ of the total national energy mix and the expounded petroleum resources are predicted to run out in about 12.26 years [1].

To overcome this, the Indonesian government seeks to increase the use of non-fossil energy in the form of new and renewable energy (RE) through Government Regulation (PP) No. 79/2014 concerning the National Energy Policy (KEN), where the target of RE utilization in 2025 increases to $23 \%$ while energy utilization from petroleum decreases to $25 \%$ [1].

Biomass is biological material derived from plants and animals and consists of large amounts of carbon and other elements in smaller amounts such as nitrogen, oxygen, hydrogen, alkaline earth, and heavy metals. This type of energy is included in a renewable energy source because trees and other living things can reproduce and grow back. The raw material for making biomass which is always available is an inexhaustible and renewable source of energy. Many products can be generated from biomass, for example biomass can be used as a power source, a source of biofuel $\mathrm{d}$ an others.

Renewable energy sources are environmentally friendly energy sources that do not pollute the environment and do not contribute to climate change and global warming. Biogas is an alternative energy which is currently being developed. Besides being cheap, biogas is also environmentally friendly. Making biogas is simple, namely by inserting a substrate in the form of cow dung or organic waste into a tightly closed digester container, in some time it will produce gas as an energy source [2].

The biogas produced from the organic waste fermentation process does not contain $100 \%$ flammable gas. Products biogas consists of methane $\left(\mathrm{CH}_{4}\right) 55-65 \%$, carbon dioxide $\left(\mathrm{CO}_{2}\right) 35-45 \%$, nitrogen $\left(\mathrm{N}_{2}\right)$ 0-0.3\%, hydrogen $\left(\mathrm{H}_{2}\right)$ 1-5\%, hydrogen sulfide $\left(\mathrm{H}_{2} \mathrm{~S}\right)$ 0-3\%, oxygen $\left(\mathrm{O}_{2}\right)$ 0.1-0.5\%, and water vapor. 
All the elements that play a role in determining the quality of biogas, namely methane gas $\left(\mathrm{CH}_{4}\right)$ and carbon dioxide $\left(\mathrm{CO}_{2}\right)$. [3-5].

In order to produce optimal biogas, there are several factors that must be maintained in the process of biogas formation, namely the $\mathrm{pH}$ factor, the optimal $\mathrm{pH}$ value is at $6.8-7.4$ [6]. The optimum temperature biogas formation at $35^{\circ} \mathrm{C}$ [7] and $\mathrm{C} / \mathrm{N}$ ratio, is the relationship between the amount of carbon and nitrogen. For anaerobic digesters, the $\mathrm{C} / \mathrm{N}$ value is between $20-30$. If the $\mathrm{C} / \mathrm{N}$ is too high, the biogas production will be low, if the $\mathrm{C} / \mathrm{N}$ is too low, nitrogen will accumulate to form ammonia [8].

The purity of the $\mathrm{CO}_{2}$ and $\mathrm{H}_{2} \mathrm{~S}$ content in biogas is important because it affects the resulting calorific value and the lifespan of the biogas-using equipment. The $\mathrm{CH}_{4}$ content in biogas can be increased $75-98 \%$ by removing the $\mathrm{CO}_{2}$ and $\mathrm{H}_{2} \mathrm{~S}$ content [9]. In this case the impurity which affects the heating value is carbon dioxide $\left(\mathrm{CO}_{2}\right)$. The presence of $\mathrm{CO}_{2}$ in $\mathrm{CH}_{4}$ gas is very undesirable, this is because carbon dioxide is an inhibitor of the rate of chemical combustion reactions in machinery [10]. The lower the level of $\mathrm{CO}_{2}$ in $\mathrm{CH}_{4}$ the higher the heating value of $\mathrm{CH}_{4}$, indicated by the yellowish red color in the resulting flame [11]. $\mathrm{CO}_{2}$ reduces the rate of propagation of the combustion flame because the $\mathrm{CO}_{2}$ molecule inhibits the collision reaction between the hydrocarbon refrigerant molecules and the air molecules [12]. The $\mathrm{CO}_{2}$ content can also reduce the thermal efficiency of diesel engines. The optimal methane content of biogas for engine fuel is more than $90 \%$ [13].

In the production process of making biogas, the resulting biogas product must contain $\mathrm{H}_{2} \mathrm{~S}$ ranging from 100-10000 ppm, the $\mathrm{H}_{2} \mathrm{~S}$ content depends on the type of biomass and organics contained [14]. $\mathrm{H}_{2} \mathrm{~S}$ has been identified as a compound that causes problems in its use in machining because $\mathrm{H}_{2} \mathrm{~S}$ causes mechanical components to corrode [15]. The use of biogas which contains $\mathrm{H}_{2} \mathrm{~S}$ produces sulfur and sulfuric acid which are corrosive to various types of metals. $\mathrm{H}_{2} \mathrm{~S}$ content of 200 ppm if inhaled by humans for 30 minutes can cause death. The maximum permit for $\mathrm{H}_{2} \mathrm{~S}$ for safety and health standards is $20 \mathrm{ppm}$ [16]. When the $\mathrm{H}_{2} \mathrm{~S}$ contained in this biogas burns, the $\mathrm{H}_{2} \mathrm{~S}$ will turn into sulfur oxide which will cause corrosion to metal components and make engine lubricant oil acidic. To reduce the damage caused by $\mathrm{H}_{2} \mathrm{~S}$ the compounds $\mathrm{H}_{2} \mathrm{~S}$ should be eliminated or reduced abortion up to the limit of tolerance $[17,18]$.

To increase the benefits of biogas as renewable energy, it is necessary to carry out the methane refining stage. Biogas purification techniques can be performed using $\mathrm{a} b$ sorption, namely the separation of a specific gas from a mixture of gases by way of transfer of mass into a liquid solvent that has a different selectivity of gas which would remove. Various kinds of biogas purification methods include physical absorption, chemical absorption, membrane separation absorption, cyrogenic and chemical conversion into other compounds $[19,20]$. It is also available to capture $\mathrm{CO}_{2}$ with various solvents such as monoethanolamine, ammonia, tetrahydrofuran, and tetra-n-butyl ammonium bromide [21, 22].

\section{EXPERIMENTAL}

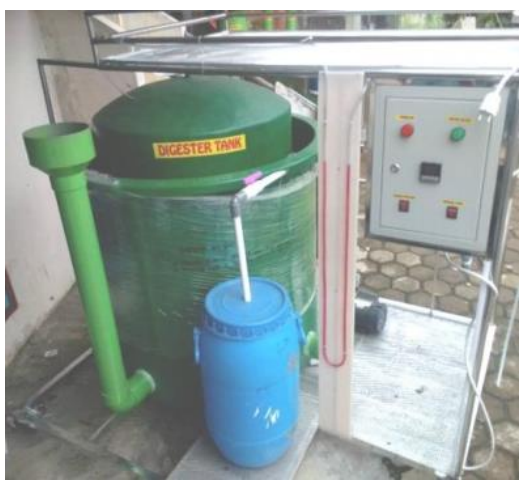

Figure 1. Biogas Digester

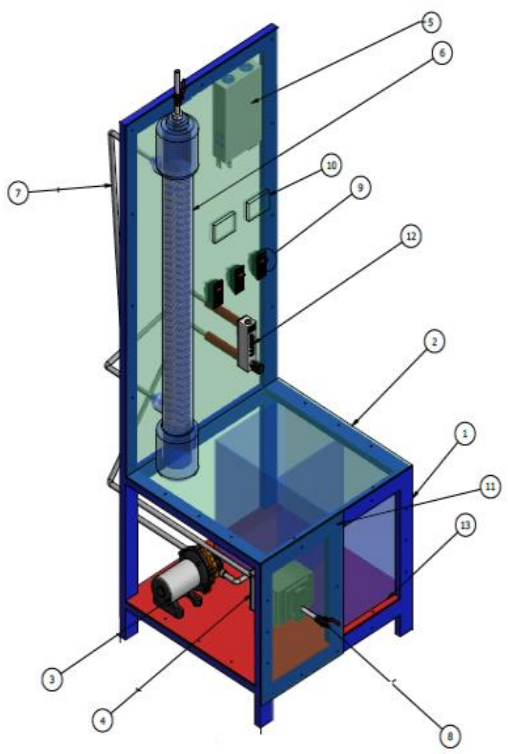

Annotation:

1. Frame Unit

2. Set Acrylic

3. Water Pump

4. Biogas Pump

5. Power supply

6. Scrubber

7. Storage

8. Biogas Inlet

9. Control Panel

10. Scrubber Temperture Indicator

11. Rivet Nail

12. Biogas Flowmeter

13. Storage Solution

Figure 2. Purification Biogas with packed bed scrubber 
In this study the biogas from cow manure produced by the digester with a volume of 500 liters. Biogas raw materials consist of cow dung and water in ratio of $1: 2$ and its left to rest during fermentation process. Biogas analyzed the results composition by interval 5 days, biogas which is day $5,10,15,20,25,30$, and 35 to know the optimum composition of biogas, then once obtained optimum conditions biogas. The biogas digester used in this study can be seen in Figure 1.

Purification of the biogas with monoethanolamine (MEA) $7 \mathrm{M}$, the flow rate of MEA solution $1.5 \mathrm{~L} /$ minute with variations in the biogas flow rate of $5,10,15,20$, 25 and $30 \mathrm{~L} /$ minute. The equipment used in this study can be seen in Figure 2.

The results of biogas production during the fermentation process are analyzed at interval every 5 days using the Shimadzu Gas Chromatography to determine the composition of biogas with parameters such as $\mathrm{CH}_{4}, \mathrm{CO}_{2}, \mathrm{O}_{2}$, and $\mathrm{H}_{2} \mathrm{~S}$.

\section{RESULTS AND DISCUSSION}

\subsection{Biogas composition analysis}

The fermented biogas product at intervals of 5 days are collected in a biogas bag before purification by using of a MEA. Biogas fermentation occurs due to the help of microorganisms that function as decomposers of raw materials, fermentation process occurs for 35 days with maintained temperature and $\mathrm{pH}$. Biogas product can be seen in Figure 3.

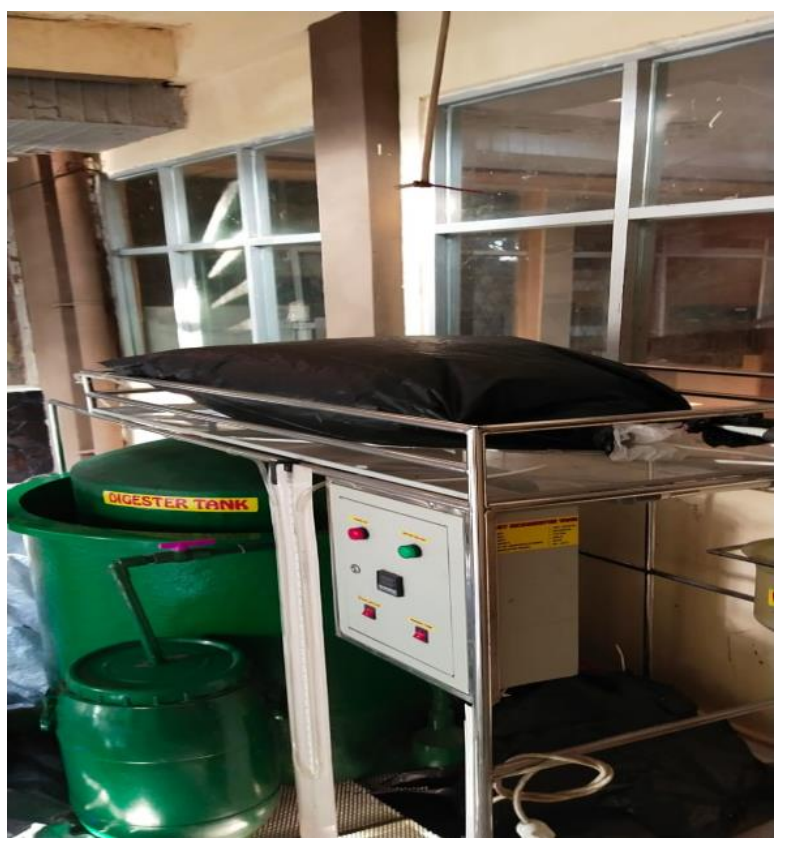

Figure 3. Biogas Product

The results of the biogas composition using gas chromatography GC-2014 Shimadzu can be seen in Tabel 1.
Tabel 1. Biogas Composition Analysis Result From biogas at $25^{\text {th }}$ day

\begin{tabular}{|c|c|c|c|c|c|}
\hline Name & $\begin{array}{c}\text { Ret. } \\
\text { Time }\end{array}$ & Area & Height & Conc & Unit \\
\hline $\mathrm{CH}_{4}$ & 1,155 & 59794472 & 17583630 & 68,18 & $\%$ \\
\hline Total & & 59794472 & 17583630 & & \\
\hline
\end{tabular}

Biogas composition before purified was analyzed using gas chromatography and the results in Table 2.

Table 2. Analysis of the biogas composition before purification

\begin{tabular}{|c|c|c|c|c|}
\hline Day & $\begin{array}{c}\mathrm{CH}_{4} \\
(\%)\end{array}$ & $\mathrm{CO}_{2}(\%)$ & $\mathrm{H}_{2} \mathrm{~S}(\mathrm{ppm})$ & $\mathrm{O}_{2}(\%)$ \\
\hline 5 & 21.73 & 1.34 & 103 & 20.12 \\
\hline 10 & 33.62 & 5.76 & 147 & 18.13 \\
\hline 15 & 47.01 & 8.24 & 170 & 12.13 \\
\hline 20 & 56.42 & 10.17 & 256 & 10.13 \\
\hline 25 & 68.18 & 13.03 & 327 & 7.13 \\
\hline 30 & 58.34 & 9.42 & 420 & 5.68 \\
\hline 35 & 20.22 & 1.64 & 459 & 2.13 \\
\hline
\end{tabular}

The fermented biogas product that has been accommodated in the biogas bag is purified using a packed bed scrubber with MEA solution as absorbent and stainless steel as packing. Purified biogas product can be seen in Figure 4.

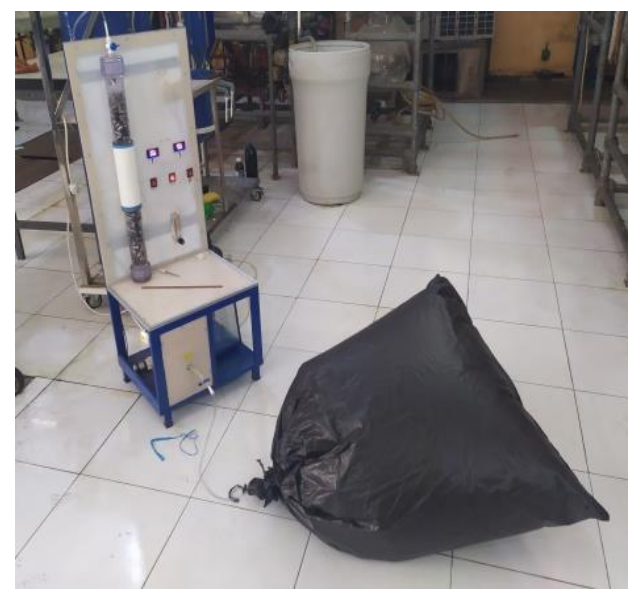

Figure 4. Purified Biogas Product

The composition of the biogas after purification with $7 \mathrm{M}$ MEA solution and varying the biogas flow rate can be seen in Table 3 . 
Table 3. Analysis of the biogas composition after purification with 7M MEA solution

\begin{tabular}{|c|c|c|c|c|}
\hline $\begin{array}{c}\text { Biogas } \\
\text { flow rate } \\
(\mathrm{L} / \mathrm{min})\end{array}$ & $\mathrm{O}_{2}(\%)$ & $\mathrm{CH}_{4}(\%)$ & $\mathrm{CO}_{2}(\%)$ & $\begin{array}{c}\mathrm{H}_{2} \mathrm{~S} \\
(\mathrm{ppm})\end{array}$ \\
\hline 5 & 7.26 & 87.6 & 0.07 & 4 \\
\hline 10 & 6.50 & 85.63 & 0.11 & 15 \\
\hline 15 & 6.53 & 83.21 & 0.26 & 31 \\
\hline 20 & 6.72 & 80.25 & 0.41 & 46 \\
\hline 25 & 7.20 & 77.72 & 0.72 & 51 \\
\hline 30 & 6.93 & 73.63 & 1.06 & 63 \\
\hline
\end{tabular}

The results of the biogas composition using gas chromatography for a biogas flow rate of $5 \mathrm{~L} / \mathrm{min}$ can be seen in Tabel 4.

Tabel 4. Biogas Composition Analysis Result From Cow Manure at $25^{\text {th }}$ day

\begin{tabular}{|c|c|c|c|c|c|}
\hline Name & $\begin{array}{c}\text { Ret. } \\
\text { Time }\end{array}$ & Area & Height & Conc & Unit \\
\hline $\mathrm{CH}_{4}$ & 1,225 & 59878123 & 17581741 & 87,60 & $\%$ \\
\hline Total & & 59878123 & 17581741 & & \\
\hline
\end{tabular}

\subsection{Effect of biogas flow rate on methane gas content}

When purifying the biogas produced with 7M MEA solution, the biogas flow rate was varied to see its effect on the amount of methane gas produced. The results of measurement and analysis of biogas purity based on the biogas flow rate can be seen in Figure 5.

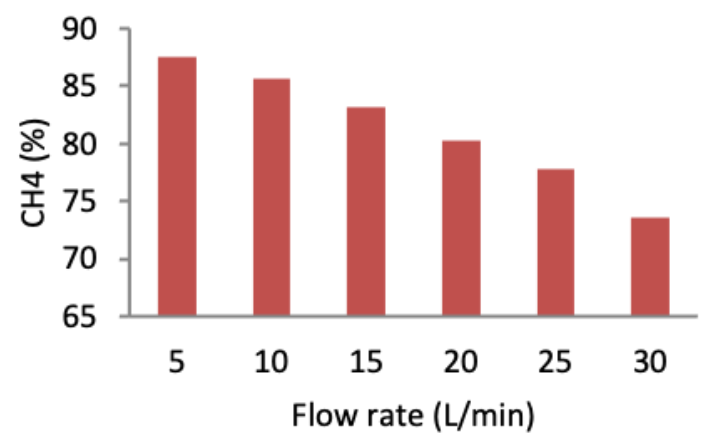

Figure 5. Effect of biogas flow rate on methane gas production

It can be seen in Figure 4 that the higher the flow rate will cause the absorption of $\mathrm{CH}_{4}$ in the biogas to decrease, this is because the biogas flow rate causes the absorption between the MEA solution in the biogas to be less than optimal. The results of biogas analysis after purification showed very significant at a biogas flow rate $5 \mathrm{~L} / \mathrm{min}$ with concentration of $7 \mathrm{M}$ MEA able to reach $87.6 \%$ methane compared with a biogas flow rate of $10 \mathrm{~L} / \mathrm{min}$ to $30 \mathrm{~L} / \mathrm{min}$.

\subsection{Effect of Biogas Flow rate $\mathrm{CO}_{2}$ Production}

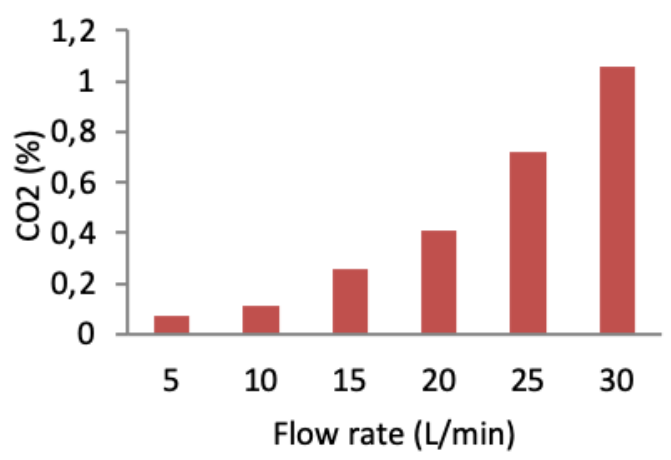

Figure 6. Effect of biogas flow rate on $\mathrm{CO}_{2}$ gas production

According to Figure 6 that the higher flow rate will cause absorption of $\mathrm{CO}_{2}$ in the biogas decreases this is caused because the flow rate of biogas cause absorption between the MEA solution becomes less optimal biogas. Increasing the flow rate of biogas makes the $\mathrm{CO}_{2}$ content increases. From this research, it was found that the greater the biogas flow rate, the $\mathrm{CO}_{2}$ production will also increase.

\subsection{Effect of Biogas Flow Rate to $\mathrm{H}_{2} \mathrm{~S}$ production}

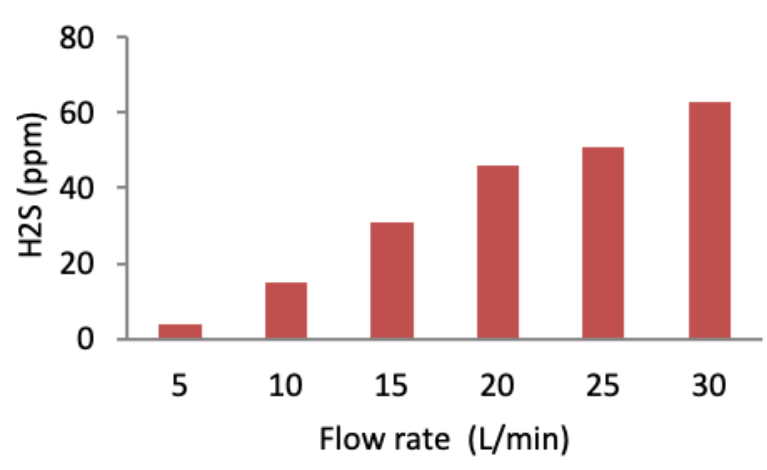

Figure 7. Effect of biogas flow rate on $\mathrm{H}_{2} \mathrm{~S}$ gas production

From the Figure 7, increasing the flow rate biogas make $\mathrm{H}_{2} \mathrm{~S}$ content increase. Concentration $\mathrm{H}_{2} \mathrm{~S}$ in biogas has increased from 4 to $63 \mathrm{ppm}$. From this research proved that the lower flow rate of biogas can reduces $\mathrm{H}_{2} \mathrm{~S}$.

\section{CONCLUSION}

Biogas produced from cow manure can be obtained after 25 days with methane gas content reached $68.18 \%$ before purification. After being purified with $7 \mathrm{M}$ 
monoethanolamine (MEA) solution, the amount of methane gas increased to $87.6 \%$ at a biogas flow rate of $5 \mathrm{~L} /$ minute. In this condition the $\mathrm{H}_{2} \mathrm{~S}$ and $\mathrm{CO}_{2}$ levels decrease while the $\mathrm{O}_{2}$ levels increase.

\section{AUTHORS' CONTRIBUTIONS}

All of the authors are involved in the process of designing the equipment and biogas product. The first and corresponding author contribution is responsible for data processing and manuscript writing. The second author is responsible for equipment design and data processing. The third and fourth authors are responsible for analysis biogas composition. The fifth author is responsible for funding arrangement.

\section{ACKNOWLEDGMENTS}

We would like to thank the Politeknik Negeri Sriwijaya for funding and facilitating the assignment research in 2020.

\section{REFERENCES}

[1] Anindhita, I. Rahardjo, I. Fitriana, and R. Etie Puspita Dewi, Outlook Energi Indonesia 2018. Jakarta: Pusat Pengkajian Industri Proses dan Energi (PPIPE) Badan Pengkajian dan Penerapan Teknologi (BPPT), 2018.

[2] R Ploetz, R Rusdianasari, and E Eviliana, Renewable Energy: Advantages and Disadvantages Proceeding Forum in Research, Science, and Technology (FIRST), pp. E1-E4, 2016.

[3] RAN Moulita, Rusdianasari, L Kalsum, Converting Waste Cooking Oil into Biodiesel using Microwaves and High Voltage Technology, Journal of Physics: Conf. Series 1167(012033), 2019

[4] S Yunsari, Rusdianasari, A Husaini, CPO Based Biodiesel Production using Microwaves Assisted Method, Journal of Physics: Conf. Series 1167(1) 012036, 2019

[5] P Dilia, K Leila, Rusdianasari, Fatty Acids from Microalgae Botryococcusbraunii for Raw Material of Biodiesel, Journal of Physics: Conf. Series 1095(012010), 2018.

[6] Rusdianasari, A Syarif, M Yerizam, MS Yusi, L Kalsum, Y Bow, Effect of Catalyst on the Quality of Biodiesel from Waste Cooking oil by Induction Heating, Journal of Physics: Conf. Series 1500 (012052), 2020

[7] Suminto, D. A. Susanto, R. Lukiawan, B. S. Nasional, and G. M. Wanabakti, Standards
Requirement in Supporting the Development of New Energy Sources (Biogas), pp. 9-19, 2013.

[8] R. J. Teodorita Al Seadi, Domiik Rutz, Heinz Prassl, Michael Kottner, Tobias Finsterwalder, Silke Volk, biogas HANDBOOK. Esbjerg: University of Southern Denmark Esbjerg, Niels Bohrs Vej 9-10, DK-6700 Esbjerg, Denmark, 2008.

[9] Fachagentur Nachwachsende Rohstoffe e. V., Guide to Biogas: From production to use. Eschborn: Fachagentur Nachwachsende Rohstoffe e. V. (FNR) FNR, 2012.

[10] S. S. Mulyawan, D. W. Aghnia, E. Rianawati, and E. Damanhuri, The Study of Rice Husk as Co-Digestion Together with Cow Dung is Biogas Production of Anaerobic Digester, vol. 13, 2018.

[11] M. Stucki, Matthias; Jungbluth, Niels; Leuenberger, Life Cycle Assessment of Biogas Production from Different Substrates, ESUservices Ltd., p. 84, 2011.

[12] H. Hadiyanto and R. Hendroko, Integrated Biogas-Microalgae from Waste Waters as the Potential Biorefinery Sources in Indonesia, Energy Procedia, vol. 47, pp. 143-148, 2014.

[13] M. Khalil, M. Ali, R. Heryanto, and A. Rizalie, Waste to energy technology: The potential of sustainable biogas production from animal waste in Indonesia, Renew. Sustain. Energy Rev., vol. 105, pp. 323-331, 2019.

[14] Sajaruddin, L. Kalsum, and Z. Muchtar, "The Analysis of Biogas Fermentation Time from Cow Manure on Fixed Dome Biodigester Batch Systems," in Journal of Physics: Conference Series 1500(0120430), 2020.

[15] S Susumu, R Rusdianasari, S Yusi 2018 Biodiesel Production from Waste Cooking Oil using Electrostatic Method Indonesia Journal of Fundamental and Applied Chemistry (IJFAC) 3(3)

[16] JU Putra, L Kalsum, Y Bow 2018 Effect of DC Voltage on Prototype of Biodiesel Electrostatic Separator with Glyserin from Waste Cooking Oil Indonesia Journal of Fundamental and Applied Chemistry (IJFAC) 3(3)

[17] E Anzar, S Yusi, Y Bow 2018 Purification of Crude Glycerol for Biodiesel By-product by Adsorption using Bentonite Indonesia Journal of 
Fundamental and Applied Chemistry (IJFAC) 3(3)

[18] I N Daiyan, L Kalsum, Y Bow, Capturing CO2 from Biogas by MEA (mono ethanolamine) using Packed bed Scrubber, J. Tek. Kim. Ling. 4(2), 2020

[19] ES Yusmartini and Rusdianasari 2016 Separation process Biodiesel from Waste Cooking Oil using Ultrafiltration Membranes Proceeding Forum in Research, Science, and Technology (FIRST)

[20] L. Kalsum, A. Hasan, Rusdianasari, A. Husaini, and Y. Bow, Evaluation of Main Parameter
Process of Anaerobic Digestion of Cow Dung in Fixed Dome Biodigester on Methane Gas Quality, in Journal of Physics: Conference Series 1500(012060), 2020.

[21] RAN Moulita, R Rusdianasari, L Kalsum 2020 Biodiesel production from Waste Cooking Oil using Induction Heating Technology Indonesia Journal of Fundamental and Applied Chemistry (IJFAC) 5(1)

[22] Rusdianasari, Y Bow, RAN Moulita 2020 Temperature Effect on the Biodiesel Quality from Waste Cooking Oil by Induction Heating Journal of Physics: Conf. Series 1450012003 